Yanti Yandri Kusuma ${ }^{1}$

\title{
ANALISIS KESIAPAN GURU KELAS DALAM PENGELOLAAN KELAS PADA MATA PELAJARAN TEMATIK DI SD PAHLAWAN
}

\begin{abstract}
Abstrak
Penelitian ini bertujuan untuk mendeskripsikan perencanaan, pelaksanaan, pengawasan dan penilaian dalam pengelolaan kelas di kelas dua SD Pahlawan. Penelitian ini merupakan penelitian kualitatif dengan jenis penelitian fenomenologi. Subjek dalam penelitian ini adalah guru kelas Dua, siswa kelas Dua, dan kepala sekolah. Objek penelitian ini berupa bentuk untuk kesiapan guru kelas dalam mengimplementasikan Pengelolaan Kelas. Teknik pengumpulan data dalam penelitian ini menggunakan teknik observasi, wawancara, dan dokumentasi. Data dianalisis dengan menggunakan reduksi data, display data, dan penarikan kesimpulan. Uji keabsahan data menggunakan triangulasi teknik, sumber, dan waktu. Hasil penelitian ini menunjukkan bahwa guru kelas satu sudah membuat perencanaan pembelajaran berupa RPP. Pelaksanaan pembelajaran guru kelas satu sudah menggunakan pendekatan saintifik walau tidak urut 5M serta sudah mengacu rambu-rambu dan prinsip pembelajaran tematik. Guru kelas satu menggunakan penilaian autentik yang menilai aspek sikap dengan observasi, aspek pengetahuan dengan tes tertulis serta penugasan, dan aspek keterampilan dengan unjuk kerja
\end{abstract}

Kata Kunci: Guru Kelas, Pengelolaan Kelas, Mata PelajaranTematik

\begin{abstract}
This study aims to describe planning, implementation, and assessment in implementing classroom management thematic learning in the first grade of SD Pahalwan. This researchis a qualitative research with a type of phenomenological research. The subjects in this study were first grade teachers, first class students, and school principlas. The object of this research is in the from of class teacher readiness in implementing thematic learning. Data collection techniques in this study used observation, interview, and documentation techniques. The data is analyzed using data reduction, data display, and conclusion. Test the validity of the data using triangulation techniques, sources, and time. The results of this study indicate that first grade teachers have made lesson plans in the form of lesson plans. In implementation of learning in first grade teachers has used the scientific approach even though it is not in $5 \mathrm{M}$ sequence and has referred to signs and thematic learning principles. First grade teachers use authentic assessment that assesses aspects of attitude with observation, aspects of knowledge with written tests and assignments, and aspects of skills with performance.
\end{abstract}

Keywords: Classroom Teacher, Classroom Management, Thematic Subjects

\footnotetext{
${ }^{1}$ Pendidikan Guru Sekolah Dasar, Fakultas Ilmu Pendidikan, Universitas Pahlawan Tuanku Tambusai Alamat email zizilia.yanti@gmail.com
} 


\section{PENDAHULUAN}

Pendidikan merupakan tolak ukur dalam status sosial. Hal ini terjadi karena pendidikan dapat mempengaruhi, merubah, bahkan mengembangkan pandangan, sikap, dan keterampilan hidup seseorang. Dalam pasal 31 Undang-undang Dasar Negara Republik Indonesia Tahun 1945 menyebutkan bahwa setiap warga negara berhak mendapat pendidikan. Menurut UU RI No 20 Tahun 2003 terdapat tiga jalur pendidikan yang dapat diterapkan, yaitu pendidikan formal, pendidikan informal, dan pendidikan non-formal.

Pendidikan dapat menentukan kemajuan sebuah negara dan pendidikan juga menentukan masa depan bangsa Indonesia. Masa depan bangsa Indonesia terletak pada tangan generasi mudah. Mutu bangsa ini kemudian hari akan bergantung pada pendidikan yang mereka dapat, terutama melalui pendidikan formal yang mereka terima disekolah. Apa yang akan didapat oleh peserta didik disekolah ditentukan oleh profesionalisme guru.

Dilingkungan sekolah, guru adalah aktor utama untuk mewujudkan kesuksesan pendidikan. Tanpa keterlibatan aktif guru, pendidikan kosong dari materi, esensi, dan subtansi. Menurut Ngainun Naim (2009:1) guru adalah sosok yang rela mencurahkan sebagian besar waktunya untuk mengajar dan mendidik peserta didik. Sedangkan menurut Chotimah dalam Darmadi (2018:14) mengatakan guru adalah orang yang memfasilitasi alih ilmu pengetahuan dari sumber belajar kepada peserta didik. Seorang guru tentu memiliki ilmu dasar atau bekal yang akan disampaikan pada peserta didik.

Guru juga merupakan jabatan atau profesi yang membutuhkan keahlian khusus. Guru haruslah menjadi sosok dambaan peserta didik yang senantiasa menjadi teladan yang dicontoh dan ditiru oleh peserta didik dimanapun berada. Pekerjaan sebagai guru tidak bisa dilakukan oleh seseorang tanpa mempunyai keahlian sebagai guru. Menjadi seorang guru dibutuhkan syarat-syarat khusus, apa lagi jika menjadi seorang guru yang profesional maka harus menguasai seluk beluk pendidikan serta mengajar dengan berbagai ilmu pengetahuan lainnya yang harus dikembangkan melalui masa pendidikan tertentu.

Guru menjadi faktor yang menentukan mutu pendidikan karena guru berhadapan langsung dengan peserta didik dalam proses pembealajaran dikelas. Ditangan guru, mutu dan kepribadian peserta didik dibentuk. Karena itu, perlu sosok guru yang kompeten, bertanggung jawab, terampil, dan berdedikasi tinggi.

Pendidikan nasional kita masih menghadapi berbagai macam persoalan. Salah satu persoalan pendidikan kita yang masih menonjol saat ini adalah adanya kurikulum yang silih berganti. Kurikulum adalah dasar pijakan bagi pendidik dan tenaga kependidikan untuk mencapai tujuan yang telah ditetapkan. Menurut Hilda Taba dalam Munir (2008:27) mendefinisikan kurikulum sebagai rencana belajar dan mengungkapkan bahwa a curiculum is a for learning, dengan kata lain kurikulum adalah rencana pendidikan atau pembelajaran.

Sedangkan menurut Nana Syaodih Sukmadinata (2010) kurikulum adalah suatu rencana yang memberi pedoman atau pegangan dalam proses kegiatan belajar mengajar. Kurikulum merupakan inti bidang pendidikan dan memiliki pengaruh terhadap seluruh kegiatan pendidikan. Kurikulum berfungsi sebagai pedoman dalam pelaksanaan kegiatan pendidikan disekolah bagi pihak-pihak yang terkait, yaitu pihak guru, kepala sekolah, pengawas, dan bagi siswa. Kurikulum memiliki enam fungsi, yaitu fungsi penyesuaian, fungsi pengintergrasian, fungsi diferensiasi, fungsi persiapan, fungsi pemilihan, dan fungsi diagnostik.

Perubahan kurikulum yang terjadi dalam dunia pendidikan di Negara Indonesia menjadikan para pendidik harus berfikir lebih mendalam dan merenungkan bahwa tidak mudah untuk melaksanakannya, karena tentu banyak hal yang harus berubah, mulai dari pola pikir, sikap, mental, strategi, metode atau cara lama yang digunakan sebelumnya dengan pola pikir dan kebiasaan yang baru.

Salah satu perubahan yang paling terlihat dari kurikulum 2013 adalah menggunakan pembelajaran tematik dari perubahan standar isi. Pembelajaran tematik merupakan pembelajaran yang mengintegrasikan kompetensi dari berbagai mata pelajaran diintegrasikan 
kedalam berbagai tema, dan dilakukan pada aspek sikap, keterampilan, dan pengetahuan didalam proses pembelajaran.

Pemahaman guru tentang pembelajaran tematik akan menentukan rancangan rencana pelaksanaan pembelajaran (RPP) dan diterjemahkan dalam bentuk kegiatan pembelajaran. untuk mengatasi hal ini pemerintah berperan penting dalam mempersiapkan seorang guru diantaranya dengan memberikan pelatihan dan memberikan buku pedoman untuk guru. Berapa pun dana yang dikeluarkan pemerintah untuk biaya pendidikan, kalau guru kurang memiliki sikap profesional dan kurang memiliki kompetensi tidak akan tercapai apa yang diharapkan.

Menurut Drs. Winarno Hamiseno pengelolaan adalah substantifa dari mengelola. Sedangkan mengelola adalahsuatu tindakan yang dimulai dari penyusunan data, merencana, mengorganisasikan, melaksanakan sampai dengan pengawasan dan penilaian.

Dari uraian tersebut dapat disimpulkan bahwa pengelolaan adalah penyelenggaraan atau pengurusan agar sesuatu yang dikelola dapat berjalan dengan lancar. Selajutnya pengertian kelas sendiri, menurut Hadari Nawawi kelas dapat dipandang dari dua sudut yaitu :

1. Kelas dalam arti sempit yakni, ruangan yang dibatasi oleh empat dinding, tempat sejumlah siswa berkumpul untuk mengikuti proses belajar mengajar.

2. Kelas dalam arti luas adalah, suatu masyarakat kecil yang merupakan bagian dari masyarakat sekolah, yang sebagai satu kesatuan diorganisasi menjadi unit kerja yang secara dinamis menyelenggarakan kegiatan kegiatan belajar mengajar yang kreatif untuk mencapai satu tujuan.

Pengelolaan kelas menurut beberapa ahli diantaranya yaitu:

Made Pidarta dengan mengutip pendapat Lois V Johson dan Mary A Bany, bahwa pengelolaan kelas adalah proses seleksi dan penggunaan alat alat yang tepat terhadap problema dan situasi kelas.

Sudirman N, dkk, pengelolaan kelas adalah kemampuan guru atau wali kelas dalam mendayagunakan potensi kelas.

Hadar Nawawi, pengelolaan kelas adalah kemampuan guru atau wali kelas dalam mendayagunakan potensi kelas berupa pemberian kesempatan

yang seluas-luasnya pada setiap personal untuk melakukan kegiatan-kegiatan yang kreatif dan terarah.

Suharsimi Arikunto, pengelolaan kelas adalah suatu usaha yang dilakukan oleh penanggung jawab kegiatan belajar mengajar atau yang membantu dengan maksud agar dicapaikondisi optimal sehingga dapat terlaksana kegiatan belajar seperti yang diharapkan.

Menurut Djamarah \& Zaini secara sederhana pengelolaan kelas berarti kegiatan pengaturan kelas untuk kepentingan pengajaran. Sedangkan menurut mulyasa pengelolaan kelas merupakan keterampilan seorang guru untuk menciptakan kondisi iklim pembelajaran yang kondusif dan mengendalikanya apabila terjadi gangguan dalam pembelajaran

Usaha guru dalam menciptakan kondisi diharapkan akan efektif apabila : Pertama, diketahui secara tepat faktor-faktor yang dapat menunjang terciptanya kondisi yang menguntungkan dalam proses belajar mengajar.

Kedua, dikenal masalah-masalah yang diperkirakan dan biasanya timbul dan dapat merusak iklim belajar mengajar. Ketiga, dikuasainya berbagai pendekatan dalam pengelolaan kelas dan diketahui pula kapan dan untuk masalah mana suatu pendekatan digunakan.

Tujuan yang diniatkan dalam setiap kegiatan belajar mengajar, baik yang sifatnya instruksional maupun tujuan pengiring akan dapat dicapai secara optimal apabila dapat diciptakan dan dipertahankan kondisi yang menguntungkan bagi peserta didik. Akan tetapi program atau tujuan kelas tidak akan berarti apabila tidak diwujudkan menjadi sebuah bentuk kegiatan.

Tujuan pengelolaan kelas pada hakekatnya telah tergantung dalam tujuan pendidikan, secara umum tujuan pengelolaan kelas adalah menyediakan fasilias dari bermacam-macam kegiatan belajar siswa dalam lingkungan social, emosional, dan intelektual dalam kelas. Fasilitas yang disediakan itu memungkinkan siswa belajar dan bekerja, terciptanya suasana 
social yang memberikan kepuasan, suasana disiplin, perkembangan intelektual, emosional, dan sikap serta apresiasi.

Tujuan pengelolaan kelas adalah agar setiap anak dikelas dapat bekerja dengan tertib sehingga segera tercapai tujuan pengajaran secara efisien dan efektif. Sebagai indikator dari sebuahkelas yang efektif adalah apabila:

a. Setiap anak terus bekerja, tidak macet, artinya tidak ada anak yang terhenti karena tidak tahu akan tugasnya yang harus dilakukan atau tidak dapat melakukan tugas yang diberikan kepadanya.

b. Setiap anak terus mengerjakan pekerjaanya tanpa membuang waktu. Artinya, setiap anak akan bekerja secepatnya agar lekas menyelesaikan tugas yang diberikan kepadanya. Apabila ada anak yang walaupun tau dan dapat melaksanakan tugasnya, tetapi mengerjakanya kurang bergairah dan mengulur waktu bekerja, maka kelas tersebut dikatakan tidak tertib.

Maka Guru Kelas Harus Menguasai Pengelolaan Kelas agar kelas teerciptanya dengan nyaman dan damai sehingga pembelajaran dikelas menjadi efekti dan efisien.

Berdasarkan latar belakang masalah diatas, untuk mempermudah dalam pembahasan dan menghindari pelebaran masalah serta kesalah pahaman, maka perlu adanya pembatasan masalah yang akan diteliti. Adapun pembatasan masalah dalam penelitian ini yaitu tentang "Kesiapan Guru Kelas dalam Mengimplementasikan Pengelolaan Kelas di SD Pahlawan"

\section{METODE}

\section{Pendekatan Penelitian}

Dalam penelitian ini, peneliti menggunakan pendekatan kualitatif. Sugiyono (2012:15) menjelaskan bahwa penelitian kualitatif adalah: Metode penelitian yang berlandaskan pada filsafat postpositivisme, digunakan untuk meneliti pada kondisi obyek yang alamiah (sebagai lawannya adalah eksperimen) dimana peneliti adalah sebagai instrumen kunci, pengambilan sampel sumber data dilakukan secara purposive and snowbaal, teknik pengumpulan dengan trianggulasi (gabungan), analisis data bersifat induktif/kualitatif, dan hasil penelitian kualitatif lebih menekankan makna dari pada generalisasi.

Bogdan dan Taylor dalam Lexy J. Moleong (2012:4) mendefinisikan penelitian kualitatif sebagai prosedur penelitian yang menghasilkan data deskriptif berupa kata-kata tertulis atau lisan dari orang-orang dan perilaku yang dapat diamati. Sedangkan menurut Ibid dalam Afifudin dan Beni Ahmad Saebani (2012:57) penelitian kualitatif adalah metode penelitian yang digunakan untuk meneliti kondisi objek yang alamiah dimana peneliti merupakan instrumen kunsi, teknik pengumpulan data dilakukan secara triangulasi. analisis data bersifat induktif, dan hasil penelitian kualitatif lebih menekankan makna dari pada generalisasi.

Penelitian kualitatif digunakan untuk mendapatkan data yang mendalam, suatu data yang mengandung makna. Penelitian kualitatif mengungkapkan situasi sosial tertentu dengan mendeskripsikan kenyataan secara benar dan relevan dari situasi yang alami. Penelitian kualitatif didasarkan pada upaya membangun pandangan mereka yang diteliti secara rinci, dibentuk dengan kata-kata, gambaran holistik dan rumit. Penelitian kualitatif menyajikan data secara holistik dengan cara deskripsi dalam bentuk kata-kata dan bahasa, pada suatu konteks khusus yang alamiah dan dengan memanfaatkan berbagai metode alamiah.

Perilaku atau situasi sosial dalam penelitian ini yaitu, kesiapan guru kelas dalam Pengelolaan Kelas pada Mata Pelajaran Tematik di SD Pahlawan di Ridan Permai. Penelitian ini menghasilkan data penjelasan tentang kesiapan guru kelas dalam pengelolaan kelas pada mata pelajaran tematik mengenai perencanaan pembelajaran, pelaksanaan pembelajaran, dan penilaian pembelajaran yang diperoleh dari observasi, wawancara, dan dokumentasi. Data tersebut dikumpulkan selama peneliti berada dilapangan. 


\section{Jenis Penelitian}

Peneliti menggunakan jenis penelitian fenomenologi, karena penelitian ini bertujuan untuk menggambarkan atau menjelaskan kesiapan guru kelas dalam Pengelolaan kelas pada mata pelajaran Tematik di SD Pahlawan. Penelitian fenomenologi mencoba menjelaskan atau mengungkapkan makna konsep atau fenomena pengalaman yang didasari oleh kesadaran yang terjadi pada beberapa individu. Penelitian fenomenologi dilakukan dalam situasi yang alami, sehingga tidak ada batasan dalam memaknai atau memahami fenomena yang dikaji. Hal ini sejalan dengan Littlejohn (2003:184) bahwa penelitian fenomenologi adalah studi tentang pengetahuan yang berasal dari kesadaran, atau cara memahami suatu objek atau peristiwa dengan mengalaminya secara sadar.

\section{HASIL DAN PEMBAHASAN \\ HASIL}

\section{A. Deskripsi Pratindakan}

Sebelum dilakukan tindakan penelitian melakukan observasi yaitu untuk mengetahui Analisis Kesiapan Guru dalam Mengimplementasikan Pengelolaan Kelas. Data yang di ambil oleh peneliti yaitu data observasi awal pada tanggal 10 Maret 2020 yang dilakukan dengan guru kelas II SD Pahlawan di Jln Ridan Permai, bahwa Kesiapan Guru Kelas dalam mengimplementasikan pengelolaan kelas pada Kelas II.

\section{B. Deskripsi Hasil Tindakan Tiap Siklus}

Tindakan yang dilakukan pada penelitian ini adalah Kesiapan Guru Kelas dalam Pengelolaan Kelas pada mata pelajaran tematik kelas II SD Pahlawan. Penelitian ini dilakukan dalam 2 siklus pada mata pelajaran Tematik. Siklus I terdiri dari 2 kali pertemuan dengan materi lingkungan alam dan lingkungan buatan.Siklus II terdiri dari 2 kali pertemuan dengan materi manfaat lingkungan alam dan manfaat lingkungan buatan.

\section{Deskripsi Hasil Tindakan Siklus I}

\section{a. Perencanaan Tindakan Siklus I}

Sebelumnya peneliti menyiapkan beberapa perencanaan dalam penerapan model pembelajaranProbing Promting. Dalam tahap perencanaan tindakan ini, langkahlangkah yang dilakukan adalah sebagai berikut:

1) Menyusun perangkat pembelajaran yang terdiri dari silabus, Rencana Pelaksanaan Pembelajaran (RPP), Lembar Tugas Siswa (LTS), yang telah disusun pada siklus I.

2) Menentukan 2 orang observer yaitu guru kelas dan teman sejawat untuk mengamati Pengelolaan kelas bagi guru,.

\section{b. Pelaksanaan Tindakan}

\section{1) Pelaksanaan Tindakan Siklus I Pertemuan 1}

Pertemuan pertama dilaksanakan pada hari Senin tangggal 7 Oktober 2019. Pokok pembahasan pada pertemuan ini yaitu materi tentang lingkungan alam. Standar kompetensi memahami lingkungan dan melaksanakan kerja sama sekitar rumah dan sekolah. Kompetensi dasar yang akan dicapai adalah menceritakan lingkungan alam dan buatan di sekitar rumah dan sekolah.Sedangkan indikator yang akan dicapai adalah lingkungan alam. Aktivitas guru, aktivitas siswa, dan aktivitas belajar siswa dengan suatu pengelolaan Kelas. digambarkan pada kegiatan awal, kegiatan inti, dan kegiatan akhir proses pembelajaran.

Kegiatan awal dilaksanakan( \pm 10 menit), sebelum pembelajaran dimulai, guru memberi salam dan mengajak peserta didik untuk berdo'a. kemudian guru mengabsen peserta didik dan guru motivasi kepada siswa menanyakan kabar guru memberikan apersepsi yang berhubungan dengan materi yang akan dipelajari, kemudian guru menyampaikan tujuan pembelajaran yang akan dicapai oleh siswa.

Berikut adalah dialog antara guru dan siswa pada kegiatan awal pembelajaran: 
Guru :Sebelum kita belajar, ibuk ingin bertanya terlebih dahulu Sebutkan pemandangan alam apa saja yang pernah anak ibuk lihat?

Siswa :Saya buk yang menjawab nya

Guru :Iya bariq silakang nak

Siswa :Sungai dan gunung buk

Guru :Iya pintar anak ibuk, sekarang anak ibuk yang cantik ini yang seyum-seyum, coba sebutkan kembali jawaban bariq tadi nak?

Siswa :Tidak tau buk

Guru :Baiklah anak-anak ibuk jawaban bariq sungai dan gunung termasuk salah satu lingkungan alam, tepuk tanggan dulu anak-anak ibuk buat bariq dan tata.

Siswa :Sungai, tidak tau buk

Guru :Tujuan pembelajaran kita pada pagi yang cerah ini adalah untuk mengetahui lingkungan alam.

Kegiatan inti dilaksanakan, kegiaatan ini ( \pm 50 menit), diawali dengan guru, guru mengajukan pertanyaan tentang materilikungan alam dan memberi siswa waktu beberapa menit untuk memikirkan jawaban tersebut. Guru membentuk siswa secara berpasangan. Guru membagikan Lembar Tugas Siswa (LTS) dan meminta siswa untuk mendiskusikan dengan pasangannya mengenai materi yang telah dipelajari. Kemudian guru memberikan sebuah permainan cabut undian nama kelompok yang kuar maka siswa menjawab pertanyaan LTS dan permainan di lanjutkan kembali nama kelompok yang kuar maka siswa menanggapi jawaban. Guru bersama siswa memeriksa hasil diskusi kelompok yang sudah dipelajari. Guru memberi penghargaan kepada siswa terhadap siswa yang menjawab dengan benar dan menanggapi jawaban.

Kegiatan akhir dilaksanakan selama, $( \pm 10$ menit $)$, guru bersama siswa menyimpulkan materi pembelajaran. Guru bersama siswa berdo'a untuk mengakhiri proses pembelajaran.

\section{2) Pelaksanaan Tindakan Siklus I Pertemuan 2}

Pertemuan kedua dilaksanakan pada hari Senin 14 Oktober 2019.Pokok pembahasan yang akan dibahas pada pertemuan ini adalah lingkungan buatan. Standar kompetensi memahami lingkungan dan melaksanakan kerja sama sekitar rumah dan sekolah. Kompetensi dasar yang akan dicapai adalah menceritakan lingkungan alam dan buatan di sekitar rumah dan sekolah. Sedangkan indikator yang akan dicapai adalah lingkungan buatan.Aktivitas guru, aktivitas siswa, dan aktivitas belajar siswa pada mata pelajaran Ilmu Pengetahuan Sosial dengan penerapan model probing promtingdigambarkan pada kegiatan awal, kegiatan inti, dan kegiatan akhir proses pembelajaran.

Kegiatan awal dilaksanakan( \pm 10 menit), sebelum pembelajaran dimulai, guru memberi salam dan mengajak peserta didik untuk berdo'a. Kemudian guru memberikan apersepsi dan motivasi kepada peserta didikdengan mangajukan pertanyaan mengenai, kemudian guru menyampaikan tujuan pembelajaran yang akan dicapai oleh siswa. Dengan ini akan nampak dalam penguasaimaterioleh guru dalam pengelolaan kelas.

Berikut adalah dialog antara guru dan siswa pada kegiatan awal pembelajaran:

Guru :Sebutkan lingkungan buatan yang anak ibuk ketahui di sekitar rumah?

Siswa :Sebagian siswa menjawab pertanyaan tersebut.

Guru :Tidak boleh menjawab pertanyaan bersama-sama, siapa yang mau menjawab tunjuk tanggan sayang ibuk

Siswa :Saya buk

Guru :Iya david

Siswa :Jembatan dan jalan raya buk

Guru :Baik david terima kasih nak 


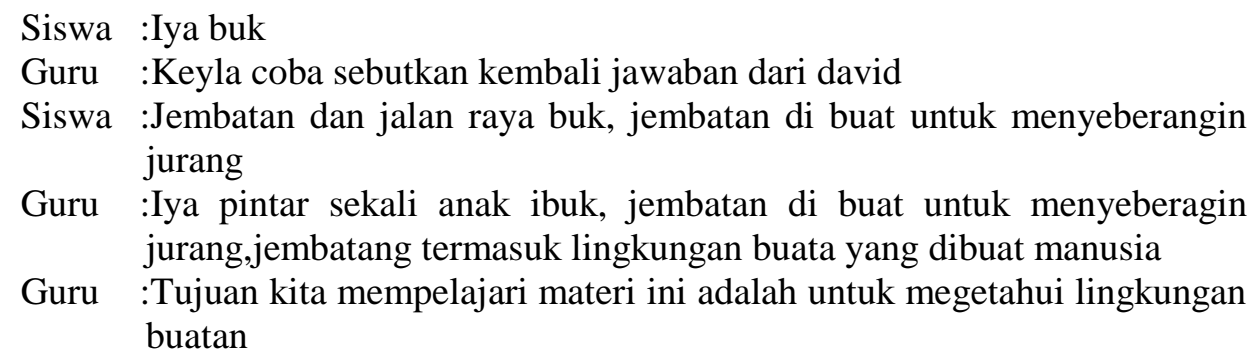

Kegiatan inti dilaksanakan $( \pm 50$ menit), kegiatan ini diawali dengan guru menjelaskan materi tentang lingkungan buatan, kemudian guru mengajukan pertanyaan tentang materi tersebut dan memberi siswa waktu beberapa menit untuk memikirkan jawaban tersebut. Guru membentuk siswa secara berpasangan. Guru membagikan Lembar Tugas Siswa (LTS) dan meminta siswa untuk mendiskusikan dengan pasangannya mengenai materi yang telah dipelajari. Kemudian guru memberikan sebuah permainan cabut undian nama kelompok yang kuar maka siswa menjawab pertanyaan LTS dan permainan di lanjutkan kembali nama kelompok yang kuar maka siswa menanggapi jawaban. Guru bersama siswa memeriksa hasil diskusi kelompok yang sudah dipelajari. Guru memberi penghargaan kepada siswa terhadap siswa yang menjawab dengan benar dan menanggapi jawaban.

Kegiatan akhir dilaksanakan selama $( \pm 10$ menit), guru bersama siswa menyimpulkan materi pembelajaran. Guru bersama siswa berdo'a untuk mengakhiri proses pembelajaran

\section{PEMBAHASAN.}

1. Sebelum Tindakan ke Siklus I

a. Aktivitas Guru

Aktivitas guru dari pratindakan ke siklus I mengalami perubahan. Hal ini dikarenakan terbukti selama proses pembelajaran dengan pengelolaan kelas oleh guru pada mata pelajaran tematik berjalan dengan cukup baik meskipun masih terdapat kekurangan dalam menyampaikan materi yang kurang jelas, kurang membimbing siswa dengan baik dan juga guru belum dapat mengkondisikan kelas dengan tertib dan nyaman.

b. Aktivitas belajar Siswa

Untuk aktivitas siswa dari pratindakan ke siklus I, siswa belum mengalami peningkatan, siswa masih terlihat kurang memperhatikan guru saat sedang menjelaskan materi pelajaran dengan melakukan aktivitas lain, siswa belum dapat menanggapi pertanyaan guru dengan baik dan belum dapat menanggapi hasil kerja kelompok lain karena masih sulit dalam mengungkapkan pendapatnya.

c. Aktivitas belajar siswa pada mata pelajaran Tematik

Berdasarkan analisis hasil penelitian diperoleh data yang berupa nilai hasil belajar siswa di Pratindakan ke siklus I. Proses pembelajaran sebelum dan sesudah dalam pengelolaan kelas pada pelajaran Tematik dikelas II materi tentang lingkungan alam dan lingkungan buatan terdapat peningkatan aktivitas belajar siswa.Peningkatan aktivitas siswa dapat dilihat dari pratindakan siswa sebelum diterapkan modelProbing Promting,Pada indikator yang pertama sudah mengalami peningkatan. Hal ini dapat dilihatpada siklus I pertemuan 1 dari $12,5 \%$ meningkat menjadi $65,5 \%$. Sedangkan pada siklus II pertemuan 1 persentase indikator menanggapi siswa mencapai $95,2 \%$ dan pada siklus II pertemuan 2 persentase indikator menanggapi siswa mencapai $90,4 \%$.

Indikator yang kedua persentase indikator bertanya siswa mengalami peningkatan dari tahap demi tahap. Hal ini dapat dilihatpada siklus I pertemuan 1 meningkat menjadi $12,5 \%$, dan pada siklus I pertemuan 2 persentase indikator bertanya siswa mengalami peningkatan menjadi $72,3 \%$.Sedangkan pada siklus II pertemuan 1 persentase indikator bertanya siswa mencapai $84,7 \%$ dan pada siklus II 
pertemuan 2 persentase indikator bertanya siswa meningkat menjadi $100 \%$.Indikator yang ketiga persentase indikator berani siswa juga mengalami peningkatan. Hal ini dapat dilihatpada siklus I pertemuan 1 dari $12,5 \%$, dan pada siklus I pertemuan 2 persentase indikator berani siswa mengalami peningkatan menjadi $65,6 \%$. Sedangkan pada siklus II pertemuan 1 persentase indikator berani siswa mengalami peningkatan mencapai $90,5 \%$ dan pada siklus II pertemuan 2 persentase indikator berani siswa meningkat lagi menjadi $100 \%$.Indikator yang keempat persentase indikator mengerjakan tes siswa juga mengalami peningkatan. Hal ini dapat dilihatpada siklus I pertemuan 1 dari $12,5 \%$, dan pada siklus I pertemuan 2 persentase indikator mengerjakan tes siswa mengalami peningkatan menjadi $75,1 \%$. Sedangkan pada siklus II pertemuan 1 persentase indikator mengerjakan tessiswa mengalami peningkatan mencapai $90,5 \%$ dan pada siklus II pertemuan 2 persentase indikator berani siswa meningkat lagi menjadi $100 \%$.

Kemampuan aktivitas belajar siswa pada materi lingkungan alam dan buatan telah meningkat dan dapat dikatakan tuntas, pada siklus I pertemuan 1 ada $12,5 \%$ siswa yang tuntas dan meningkat pada siklus I pertemuan 2 menjadi 65,5\% siswa yang tuntas, Selanjutnya pada siklus II pertemuan 1 rata-rata persentase siswa yang tuntas adalah $65,5 \%$ dan meningkat pada siklus II pertemuan 2 menjadi 95,3\%

Berdasarkan penjelasan di atas dapat disimpulkan bahwa, aktivitas belajar siswa dengan kesiapan guru dalam pengelolaan kelas dapat meningkatkan aktivitas belajar siswa pada mata pelajaran Tematik materi Lingkungan alam dan buatan pada kelas II SD Pahlawan Ridan permai.

\section{SIMPULAN}

Berdasarkan hasil penelitian yang telah dilaksanakan selama dua siklus tentang kesiapan guru kelas dalam pengelolaan kelas pada mata pelajaran tematiki untuk meningkatkan belajar siswa lingkungan alam dan buatan siswa kelas II Pahlawan di Ridan Permai, hasil analisis dari siklus satu sampai kedua ternyata terdapat peningkatan belajar peserta didik dalam pengelolaan Kelas untuk menyelesaikan permasalahan.

Belajar siswa setiap siklus pada pembelajaran Tematik Di SDPahlawan di Ridan Permai sebagai beriku:

1. Pembelajaran siswa pada siklus I pertemuan 1 ada $12,5 \%$ dan meningkat pada siklus I pertemuan 2 menjadi $42,1 \%$.

2. Siklus II pertemuan 1 rata-rata persentase siswa yang tuntas adalah $75.1 \%$ dan meningkat pada siklus II pertemuan 2 menjadi 85,3\%.

\section{DAFTAR PUSTAKAf}

Ametembun. Manajemen kelas: penuntun bagi guru dan calon guru jilid I dan II. Bandung: SURI, 1981 Al Qur'an surat An Nur ayat 30.

Amin Dain Indra Kusuma. Pengantar ilmu pendidikan. Surabaya: Usaha Nasional, 1973.

Arifin. Hubungan timbal balik pendidikan agama di lingkungan sekolah dan keluarga. Jakarta: Bulan Bintang, 1972.

Arikunto Suharsimi. Pengelolaan Kelas dan Siswa Sebuah Pendekatan Evaluatif. Jakarta: PT. Raja Grafindo Persada, 1996

Azhar Imam, Pengelolaan kelas dari teori ke praktek, Yogyakarta: Insyira, 2013

Azwar Saifudin, Metode Penelitian, Yogyakarta : Pustaka Pelajar, 2011.

Bahri Syaiful Djamarah dan Aswan Zain. Strategi Belajar Mengajar. Jakarta: Rineka Cipta, 2002.

Bruce Cohen J, Sosiologi: Suatu Pengantar, Rineka Cipta, Jakarta, 1992

Daradjat Zakiyah,et.al. Ilmu Pendidikan Islam. Jakarta: Bumi Aksara, 1996.

Damsar. Sosiologi pendidikan, Jakarta: Kencana, 2011

Dadang Suhardan,. Supervisi Profesional. Bandung: Alfa Beta, 2010 
Depdikbud. Panduan manajemen sekolah. Jakarta, 1999 Departemen Pendidikan dan Kebudayaan RI, Kamus Besar Bahasa Indonesia, (Jakarta: Balai Pustaka, 1999.

Danim Sudarwan, Inovasi Pendidikan dalam Upaya Peningkatan Profesionalisme Tenaga Kependidikan, Pustaka Setia, Bandung: PT. Remaja Rosda Karya, 2002.

Fujiawati, F. S. (2015). Pemahaman Konsep Kurikulum dan Pembelajaran dengan Peta Konsep Bagi Mahasiswa Pendidikan Seni. Jurnal Pendidikan dan Kajian Seni. Vol 1, (1), (19).

Hasbullah. (2013). Dasar-dasar Ilmu Pendidikan (Edisi Revisi). Jakarta : PT Rajagrafindo Persada.

Kadir, A, dan Asrohah, H. (2014). Pembelajaran Tematik. Jakarta : PT Rajagrafindo Persada.

Malawi, I, dan Kadarwati, A. (2017). Pembelajaran Tematik (Konsep dan Aplikasi). Jawa Timur: CV AE Media Grafika.

Siregar, P. R, dan Hatika, R. G. (2019). Ayo Latihan Mengajar, Implementasi Kurikulum 2013 di Sekolah Dasar (Peerteaching dan Microteaching). Yogyakarta : Deepublish.

Sugiyono. (2012). Metode Penelitian Pendidikan (Pendekatan Kuantitatif, Kualitatif dan R\&D). Bandung : ALFABETA.

Sukardjo. M, dan Komarudin, U. (2015). Landasan Pendidikan Konsep dan Aplikasinya. Jakarta : PT Rajagrafindo Persada.

Sumarno. (2016). Peranan Guru Pendidikan Agama Islam dalam Membangunkan Karakter Peserta Didik. Al Luhab. Vol 1, (7), (125).

Sya'bani, M. A. Y. (2018). Profesi Keguruan Menjadi Guru yang Religius dan Bermatabat. Gresik : Caremedia Communication.

Wildan. (2017). Pelaksanaan Penilaian Autentik Aspek Pengetahuan, Sikap dan Keterampilan di

Sekolah atau Madrasah. Jurnal Tatsqif. Vol 15, (2) 